\title{
Coagulation Defects and Altered Hemodynamic Responses in Mice Lacking Receptors for Thromboxane $A_{2}$
}

\author{
Dennis W. Thomas, ${ }^{\star}$ Roslyn B. Mannon, ${ }^{\star}$ Peter J. Mannon, ${ }^{\star}$ Anne Latour, ${ }^{\S}$ Julie A. Oliver, ${ }^{\ddagger}$ Maureane Hoffman, ${ }^{\ddagger}$ \\ Oliver Smithies, $\|$ Beverly H. Koller, ${ }^{\S}$ and Thomas M. Coffman* \\ *Department of Medicine and ${ }^{\ddagger}$ Department of Pathology, Duke University and Durham Veterans Affairs Medical Centers, Durham, \\ North Carolina 27705; and ${ }^{\S}$ Department of Medicine and ${ }^{\|}$Department of Pathology, University of North Carolina, Chapel Hill, \\ North Carolina 27514
}

\begin{abstract}
Thromboxane $\mathrm{A}_{2}\left(\mathrm{TXA}_{2}\right)$ is a labile metabolite of arachidonic acid that has potent biological effects. Its actions are mediated by $G$ protein-coupled thromboxane-prostanoid (TP) receptors. TP receptors have been implicated in the pathogenesis of cardiovascular diseases. To investigate the physiological functions of TP receptors, we generated TP receptor-deficient mice by gene targeting. $T p^{-1-}$ animals reproduce and survive in expected numbers, and their major organ systems are normal. Thromboxane agonist binding cannot be detected in tissues from $T p^{-1-}$ mice. Bleeding times are prolonged in $\mathrm{Tp}^{-1-}$ mice and their platelets do not aggregate after exposure to $\mathrm{TXA}_{2}$ agonists. Aggregation responses after collagen stimulation are also delayed, although ADP-stimulated aggregation is normal. Infusion of the TP receptor agonist $U-46619$ causes transient increases in blood pressure followed by cardiovascular collapse in wild-type mice, but U-46619 caused no hemodynamic effect in $T p^{-1-}$ mice. $T p^{-1-}$ mice are also resistant to arachidonic acid-induced shock, although arachidonic acid significantly reduced blood pressure in $T p^{-1-}$ mice. In summary, $T p^{-1-}$ mice have a mild bleeding disorder and altered vascular responses to $\mathrm{TXA}_{2}$ and arachidonic acid. Our studies suggest that most of the recognized functions of $\mathrm{TXA}_{2}$ are mediated by the single known $T p$ gene locus. (J. Clin. Invest. 1998. 102:1994-2001.) Key words: TP receptor - gene targeting $\bullet$ platelets $\bullet$ kidney $\bullet$ shock
\end{abstract}

\section{Introduction}

$\mathrm{TXA}_{2}$ is a biologically active lipid mediator that is produced by the metabolism of arachidonic acid through the cyclooxygenase pathway. In aqueous solutions, $\mathrm{TXA}_{2}$ is rapidly hydrolyzed to $\mathrm{TXB}_{2}$, a stable and inactive metabolite. Because of its short half-life $(<30 \mathrm{~s})$, $\mathrm{TXA}_{2}$ functions primarily as an autocoid and its actions are limited to tissues in proximity to the sources of its synthesis. Previous studies have suggested that $\mathrm{TXA}_{2}$ contributes to vascular homeostasis through its actions

Address correspondence to Thomas M. Coffman, M.D., Room B3002/Nephrology (111I), Veterans Affairs Medical Center, 508 Fulton Street, Durham, NC 27705. Phone: 919-286-6947; FAX: 919-2866879; E-mail: tcoffman@acpub.duke.edu

Received for publication 3 September 1998 and accepted in revised form 13 October 1998.

J. Clin. Invest.

(C) The American Society for Clinical Investigation, Inc. 0021-9738/98/12/1994/08 \$2.00

Volume 102, Number 11, December 1998, 1994-2001

http://www.jci.org as a potent vasoconstrictor and platelet aggregant (1-3). In the kidney, $\mathrm{TXA}_{2}$ appears to regulate renal hemodynamics and sodium handling (4-8). $\mathrm{TXA}_{2}$ may also play a role in the immune system through effects on thymic cell selection (9) and through direct effects on $\mathrm{T}$ cell functions $(10,11)$. Finally, dysregulation of $\mathrm{TXA}_{2}$ synthesis and actions has been implicated in the pathogenesis of a number of disease states including cardiovascular disease (12), asthma (13), eclampsia $(14,15)$, and a variety of kidney diseases $(3,16-18)$.

The actions of $\mathrm{TXA}_{2}$ are mediated by cell surface receptors (thromboxane-prostanoid receptors, by convention designated $\mathrm{TP})^{1}$ which are members of the $\mathrm{G}$ protein-coupled receptor superfamily (19). TP receptors are expressed in a number of tissues including thymus, platelets, lung, kidney, spleen, and placenta $(20,21)$. While the thromboxane receptors that have been cloned to date demonstrate substantial homology (2022), earlier pharmacological studies had suggested heterogeneity of function and agonist binding characteristics (23-27). For example, in mesangial cells, vascular smooth muscle cells, and platelets, activation of the thromboxane receptor is associated with rapid increases in intracellular calcium that are dependent on phospholipase $\mathrm{C}$ activation $(5,25,28,29)$, whereas in macrophages the TP receptor may be linked to adenyl cyclase (30). A structural basis for these differences in second messenger coupling and ligand binding affinities has not been determined clearly. It has been hypothesized that these differences in biochemical properties might be mediated by $\mathrm{TP}$ receptor isoforms encoded by distinct genes. However, so far only a single TP receptor gene locus ( $T p$ ) has been identified (31).

Experiments defining roles for $\mathrm{TXA}_{2}$ in physiological processes have relied primarily on pharmacological inhibitors of thromboxane synthase or thromboxane receptor antagonists. These pharmacological approaches have inherent limitations related to the potency, specificity, and dosage of individual agents. To further examine in vivo functions of TP receptors, we used gene targeting to produce TP receptor-deficient mice. Our studies suggest a key role for the TP receptor in hemostasis and regulation of certain vascular responses. In addition, our data are consistent with the existence of only one $T p$ gene.

\section{Methods}

Disruption of the Tp gene in embryonic stem (ES) cells. To clone the mouse $T p$ gene, a partial complementary DNA probe was prepared by PCR after reverse transcription of total RNA isolated from mouse lung. The PCR primer sequences were derived from the published sequence of the mouse TP receptor cDNA (21): $5^{\prime}$ primer (5'-TCTTGGTGCTTCCTGACACT-3') and 3'-primer (5'-GGAGCTGTGAA-

1. Abbreviations used in this paper: ES, embryonic stem; MAP, mean arterial pressure; PGK, phosphoglycerol kinase; PPP, platelet-poor plasma; PRP, platelet-rich plasma; TP, thromboxane-prostanoid. 
CTGAACCGC-3'). The resulting 438-bp partial cDNA fragment corresponds to the region of the TP receptor protein extending from the second extracellular loop through the proximal half of the intracellular cytoplasmic tail.

This probe was used to screen a complete BamHI-digested genomic library constructed in the lambda DashII phage vector using genomic DNA isolated from the mouse ES cell line E14tg2a. Hybridizing phages were purified and a restriction map of the genomic DNA fragment was prepared, as depicted in Fig. $1 A$. To construct the targeting vector, an 8-kb KpnI fragment containing exons 2 and 3 of the TP receptor and encompassing all of the protein coding sequences was subcloned into pBluescript KS (Stratagene Inc., La Jolla, CA). A neomycin resistance gene driven by the phosphoglycerol kinase (PGK) promoter was inserted into a unique SfiI site near the proximal end of exon 2. This insertion disrupts the coding sequence of the $T p$ gene in the third transmembrane domain. ES cells were grown, transformed, and screened using standard methodologies (32). Colonies in which the plasmid had integrated by homologous recombination were identified by Southern analysis using the $3^{\prime}$ probe shown in Fig. 1.

Generation of Tp-deficient mice. Targeted ES cells were introduced into C57BL/6 mouse blastocysts using standard techniques (32). Male chimeras were mated with B6D2 $\left(\mathrm{C} 57 \mathrm{BL} / 6 \times \mathrm{DBA} / 2 \mathrm{~F}_{1}\right.$; The Jackson Laboratory, Bar Harbor, ME) or $129 / \mathrm{SvEv}$ females to identify germline competent chimeras that were capable of transferring the genetically modified ES cell genome to their offspring. The targeted $T p$ allele was detected in offspring of these crosses by Southern blot analysis of genomic DNA isolated from tail biopsies as shown in Fig. 1. Offspring carrying the mutant allele were intercrossed to obtain animals that were homozygous for the targeted mutation $\left(T p^{-1-}\right)$.

RNA isolation and Northern analysis. Thymuses were harvested from $T p^{+/+}$and $T p^{-/-}$mice and RNA was extracted from the tissues

A
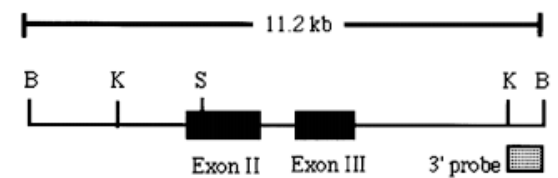

B

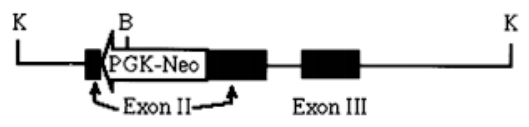

C

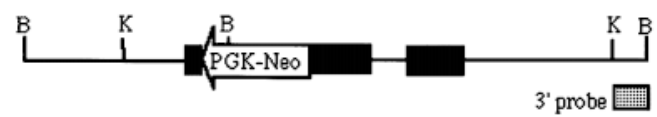

$\sqcup^{\sim} 1 \mathrm{~kb}$
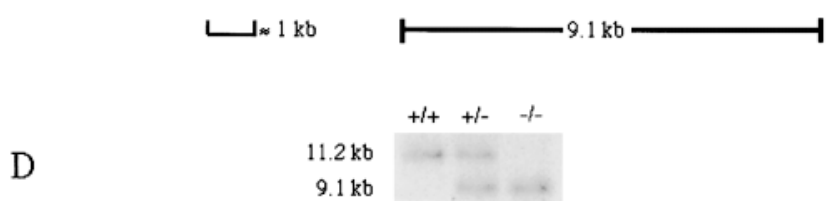

Figure 1. Targeted disruption of the mouse $T p$ gene. $(A)$ The endogenous $T p$ gene locus. Black boxes represent exons while the stippled box represents the probe used in Southern blot analysis. $B$, BamHI; $K$, KpnI; $S$, SfiI. (B) The $T p$ targeting vector. (C) The targeted $T p$ allele. $(D)$ Southern blot analysis of $T p$ mice. Genomic DNA was isolated from mouse tails, digested with restriction enzyme BamHI, separated on agarose gels, and transferred to nylon membranes. This blot was hybridized to the ${ }^{32} \mathrm{P}$-labeled DNA probe shown in the figure. The 11.2-kb band represents the endogenous wild-type $T p$ allele whereas a $9.2-\mathrm{kb}$ band identifies the targeted allele. using a commercially available reagent (Tri-reagent; Sigma Chemical Co., St. Louis, MO). $15 \mu \mathrm{g}$ of total RNA per sample was denatured and size-fractionated in glyoxal-dimethyl sulfoxide gels and transferred to nylon membranes (33). The 438-bp mouse $T p$ partial cDNA fragment that had been generated by RT-PCR (see above) was subcloned into pBluescript KS (Stratagene, La Jolla, CA) and sequenced to determine its orientation. The plasmid was then linearized and used to generate an antisense ${ }^{32} \mathrm{P}-\mathrm{CTP}$ labeled riboprobe (MAXIscript; Ambion, Inc., Austin, TX). The membranes were hybridized at high stringency and after washing, the filters were exposed to Kodak $\mathrm{X}$-AR film for up to $1 \mathrm{wk}$ at $-80^{\circ} \mathrm{C}$.

TP receptor ligand-binding studies. $\mathrm{TXA}_{2}$ receptor in thymocytes was detected using an ${ }^{125}$ I-labeled thromboxane receptor agonist IBOP (a gift from Perry Haluska) (34) [1S-(1 alpha,2 beta(5Z),3 alpha-(1E,3S)4 alpha)-7-(3-(3-hydroxy-4-(p-iodophenoxy)-1-butenyl)7-oxabicyclo(2.2.1)hept-2-yl)-5-heptenoic acid]. Thymocyte suspensions were prepared from $T p^{+/+}(n=5)$ and $T p^{-1-}(n=6)$ mice by gently grinding the thymus between glass slides. The cells were washed once in PBS and then resuspended in ice-cold PBS containing $10 \mathrm{mM}$ Tris $\mathrm{HCl}(\mathrm{pH} 7.4), 1 \% \mathrm{BSA}$, and $10 \mu \mathrm{M}$ indomethacin. Aliquots of $10^{6}$ thymocytes in triplicate were incubated with $100 \mathrm{pM}$ ${ }^{125} \mathrm{I}$-BOP for $30 \mathrm{~min}$ at $37^{\circ} \mathrm{C}$ with or without excess concentrations $(2 \mu \mathrm{M})$ of unlabeled IBOP. The incubation mixtures were filtered through Whatman GF/C glass fiber filters and the filters were washed twice with $3 \mathrm{ml}$ ice-cold incubation buffer. ${ }^{125} \mathrm{I}$ counts were determined using a gamma counter. Specific binding was calculated as the total binding minus background and binding was expressed as a percentage of the total counts that were initially added to the cells (percent specific counts).

TP receptor autoradiography. $\mathrm{TXA}_{2}$ binding in kidney sections was determined using ${ }^{125} \mathrm{I}$-BOP as described previously (27). After anesthesia with isofluorane, kidneys were removed from $T p^{+/+}$and $T p^{-1-}$ mice, the capsule was excised, the tissue was embedded in O.T.C. compound (Miles, Elkhart, IN), and frozen in liquid nitrogenchilled isopentane. Tissue blocks were sectioned serially $(20 \mu \mathrm{m})$ on a cryostat and thaw-mounted on glass microscope slides (FisherPlus; Fisher Scientific, Pittsburgh, PA). The mounted tissue sections were first preincubated in Dulbecco's PBS, pH 6.5, with $10 \mathrm{mM}$ Tris- $\mathrm{HCl}$, $2 \% \mathrm{BSA}$, and $10 \mu \mathrm{M}$ indomethacin for $10 \mathrm{~min}$ at $25^{\circ} \mathrm{C}$. The buffer was replaced with $200 \mathrm{pM}{ }^{125} \mathrm{I}$-BOP in $10 \mathrm{mM}$ PBS containing 150 $\mathrm{mM} \mathrm{NaCl}, 5 \mathrm{mM}$ EDTA, $0.3 \mathrm{mM}$ bacitracin, $2 \%$ BSA, and $10 \mu \mathrm{M}$ indomethacin. Excess concentrations $(10 \mu \mathrm{M})$ of unlabeled IBOP were added to some sections to define nonspecific binding. After incubation for $1 \mathrm{~h}$ in high humidity at $25^{\circ} \mathrm{C}$, the radioligand binding mixture was aspirated, and slide-mounted tissues were washed four times for 10 min each with ice-cold Dulbecco's PBS, pH 6.5, containing $10 \mathrm{mM}$ Tris- $\mathrm{HCl}$ and $0.5 \% \mathrm{BSA}$ and rinsed twice with ice-cold distilled water. The slides were dried, desiccated overnight at $25^{\circ} \mathrm{C}$, and then exposed to high-resolution x-ray film (Hyperfilm-betamax; Amersham International plc, Little Chalfont, Buckinghamshire, UK) for up to 1 wk. Prints were made from the tissue autoradiograms using F5 Kodabromide paper (Eastman Kodak, Rochester, NY).

Cytofluorometry. Flow cytometry on splenocytes and thymocytes was performed as described previously (35). In brief, spleen and thymus were isolated from $T p^{+/+}$and $T p^{-1-}$ mice and cell suspensions were obtained by gently grinding the tissue between sterile glass slides. Cells were resuspended $\left(2 \times 10^{6}\right.$ cells $\left./ \mathrm{ml}\right)$ in cold buffer (PBS/ $2 \% \mathrm{FBS} / 0.05 \% \mathrm{NaN}_{3}$ ). $100-\mu \mathrm{l}$ aliquots of resuspended cells were incubated with optimal concentrations of antibody for $30 \mathrm{~min}$ at $4^{\circ} \mathrm{C}$, and were washed three times in buffer. The mAbs used were: GK 1.5 (anti-CD4), 53-6.7 (anti-CD8), 30-H122 (anti-Thy 1.2) RA36B2 (antiB220), and M1/70 (anti-CD11b) (all from PharMingen, San Diego, CA). An irrelevant isotypic antibody R35-95 (rat IgG2a; PharMingen) was used as a control for nonspecific staining. After final washing, cells were fixed with PBS containing $2 \%$ formalin and were analyzed within $72 \mathrm{~h}$. Analyses and sorting were performed in a FACScan ${ }^{\circledR}$ (Becton Dickinson, Mountain View, CA). Forward scatter threshold was set to exclude dead cells and debris from acquisi- 
tion. At least $10^{4}$ cells were analyzed for each antibody or antibody combination.

Bleeding time measurement. Bleeding times were assessed in conscious mice as described by Dejana et al. (36). The mice were placed into a restraining device and their tails were secured in a vertical position throughout the test. An $\sim 3-5$-mm segment of the tail was transected using a disposable scalpel, and the remaining length of tail was immersed immediately into $37^{\circ} \mathrm{C}$ sterile isotonic saline. Bleeding time was calculated from the time of tail transection until visible bleeding could no longer be detected. If active bleeding continued for $>10 \mathrm{~min}$, the experiment was terminated and the bleeding site was cauterized.

Platelet aggregation assays. After anesthesia with isofluorane, $\sim 1$ $\mathrm{ml}$ of whole blood was removed by cardiac puncture into $10 \mathrm{U}$ of heparin. The heparinized blood was centrifuged at $100 \mathrm{~g}$ for $10 \mathrm{~min}$ at room temperature and the platelet-rich plasma (PRP) was removed. The remaining fractions were centrifuged at 2,400 $g$ and the supernatant of platelet-poor plasma (PPP) was reserved. The number of platelets in the PRP was determined using a hemacytometer and the volume was adjusted with PPP to achieve a concentration of $3 \times 10^{5}$ platelets $/ \mu$ l. Platelet aggregation was determined by light absorbance using a platelet aggregation profiler (model PAP-4; Bio/Data Corp., Horsham, PA). The baseline was set using PPP, and aggregation of individual PRP samples was determined after the addition of a series of compounds. Agents that were used to induce platelet aggregation included: $20 \mu \mathrm{M}$ U-46619; (15S)-hydroxy-11,9-(epoxymethano)prosta$5 Z, 13 E$-dienoic acid, a thromboxane receptor agonist (Cayman Chemical Co., Ann Arbor, MI); 4 MM ADP (Sigma Chemical Co., St. Louis, MO); and collagen reagent $0.05 \mathrm{mg} / \mathrm{ml}$ (Sigma Chemical Co.). After addition of agonist, platelet aggregation was monitored for 5-8 min.

Systolic blood pressure measurements in conscious mice. Systolic blood pressures were measured in conscious mice using a computerized tail cuff system (Visitech Systems, Cary, NC) that determines systolic blood pressure using a photoelectric sensor (37). This system allows pressures to be measured in four mice simultaneously and minimizes the potential for observer bias. Before the study was initiated, mice were adapted to the apparatus for at least $5 \mathrm{~d}$. The validity of this system has been established previously (37) and we have demonstrated its correlation with intraarterial pressure measurements in several experimental systems $(38,39)$.

Intraarterial blood pressure measurements and assessment of vascular responses to infusion with the TP receptor agonist U-46619 or arachidonic acid. $T p^{+/+}$and $T p^{-/-}$mice were anesthetized with isofluorane, a short length of polyethylene (PE-50) tubing was placed in the trachea to facilitate spontaneous ventilation, a flexible plastic catheter (Micro Renathane, type MRE-040, 0.040 O.D. × 0.025 I.D.; Braintree Scientific Co., Braintree, MA) was placed in the carotid artery to monitor arterial pressure, and a second catheter was placed in the jugular vein to infuse vasoactive compounds. Intraarterial blood pressure was recorded continuously through the carotid catheter using Windaq data acquisition and playback software (Dataq Instruments, Akron, $\mathrm{OH})$ as described previously $(39,40)$.

After the surgical preparation was completed, the effects of intravenous infusions of vasoactive compounds on mean arterial pressure (MAP) were determined as described previously $(39,40)$. Beginning with an equilibration period of 5-10 min, blood pressure was recorded continuously for the duration of each experiment at 50 recordings/s. To facilitate their analysis, the data collected from each animal were compressed to 5 readings/s and the MAP tracings from animals in each experimental group were integrated and averaged. Immediately after the equilibration period, the mice first received a bolus injection of $0.9 \%$ sodium chloride solution in a volume $(1 \mu \mathrm{l} / \mathrm{g}$ body wt) that was identical to the subsequent injections. In separate experiments, mice received either a single $10 \mathrm{mg} / \mathrm{kg}$ bolus of arachidonic acid (Cayman Chemical Co.) or two consecutive bolus infusions of U-46619 (100 $\mu \mathrm{g} / \mathrm{kg}$ and $1 \mathrm{mg} / \mathrm{kg}$; Cayman Chemical Co.) separated by $5 \mathrm{~min}$.

Data analysis. The values for each parameter within a group are expressed as the mean \pm SEM. For comparisons between $T p^{+/+}$and
$T p^{-1-}$ groups, statistical significance was assessed using an unpaired $t$ test. A paired $t$ test was used for comparisons within groups.

\section{Results}

Generation of Tp-deficient mice. The gene encoding the TP receptor was disrupted in the E14Tg2a ES cell line by homologous recombination with the targeting plasmid shown in Fig. 1. Sequence analysis of our genomic clone suggested that the organization of the mouse $T p$ gene is similar to that described for the human gene (31) wherein exons 2 and 3 contain the entire protein coding region. The targeting plasmid was designed to disrupt the $T p$ gene by introducing a neomycin resistance cassette into the coding regions of exon 2. Targeted ES cell lines were identified by Southern analysis and introduced into blastocysts to generate chimeric mice. Chimeras were bred to 129 / SvEv or B6/D2 mice and $T p^{+/-}$offspring carrying the mutant allele were identified by Southern analysis as shown in Fig. 1, $C$ and $D$.

Mice that were homozygous for the targeted mutation $\left(T p^{-1-}\right)$ were generated by the intercross of $T p$ heterozygous animals $\left(T p^{+-}\right)$. Among the first 124 progeny of these heterozygous crosses, $26(21 \%)$ were $T p^{+/+}, 67$ (54\%) were $T p^{+/-}$, and $31(25 \%)$ were $T p^{-1-}$. The number of $T p^{-1-}$ animals corresponded to that expected $(25 \%)$ for simple Mendelian inheritance, suggesting that the absence of the TP receptors does not adversely affect intrauterine development or perinatal survival. Furthermore, the $T p^{-1-}$ animals could not be distinguished from normal littermates by simple observation. Histological examination of heart, thymus, spleen, small intestine, lymph nodes, and aorta from the $T p^{-1-}$ animals did not reveal any pathological changes. Since the TP receptor is highly expressed in placenta (20) and uterus (21), the fertility of $T p^{-/-}$ females was also examined. The frequency of productive matings, gestation, delivery, and care of litters were not different between $T p^{+/+}$and $T p^{-/-}$females.

$T P$ receptor $m R N A$ expression in mutant mice. To verify that the targeted mutation introduced into the $T p$ gene locus resulted in inactivation of the gene, we examined expression of the TP receptor mRNA in thymus by Northern blot, because thymus is the tissue with the highest level of the TP receptor expression. Total RNA was prepared from the thymus of $T p^{+/+}$ and $\mathrm{Tp}^{-1-}$ animals and Northern blot analysis was performed using an antisense riboprobe synthesized from a TP receptor cDNA template. As shown in Fig. 2, two major bands that hybridized with the $T p$ probe were detected in RNA prepared from the thymus of wild-type $T p^{+/+}$mice including the $2-\mathrm{kb}$ band corresponds to the size of the mouse TP receptor mRNA (21). Although several aberrant transcripts were observed in $T p^{-/-}$animals, the 2-kb transcript was not detected.

$\mathrm{TXA}_{2}$ radioligand binding studies in thymocytes from $T p$ mutant mice. To verify that the absence of normal TP receptor mRNA transcripts in $T p^{-1-}$ mice was associated with the loss of functional receptors for $\mathrm{TXA}_{2}$, we examined thromboxane binding in thymocytes using the TP receptor agonist IBOP. As shown in Table I, specific ${ }^{125}$ I-BOP binding was easily detected in thymocytes from wild-type mice $(0.60 \pm 0.29 \%$ specific $\mathrm{cpm})$. In contrast, specific ${ }^{125} \mathrm{I}$-BOP binding in thymocytes from TPdeficient mice does not differ from background $(0.01 \pm 0.01 \%$ specific cpm; $P<0.0008$ vs. wild-type).

Thymocyte phenotypes are normal in $\mathrm{Tp}^{-/-}$mice. Immunohistochemical staining of thymus revealed no differences in the 
A

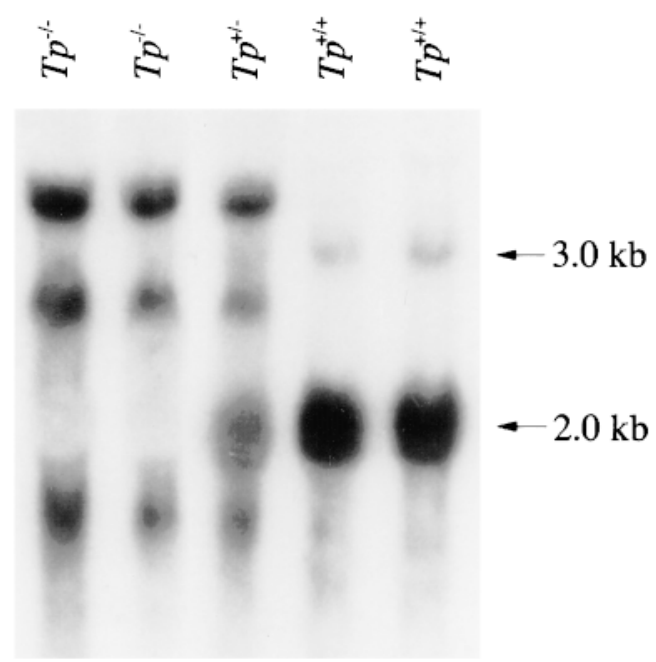

B

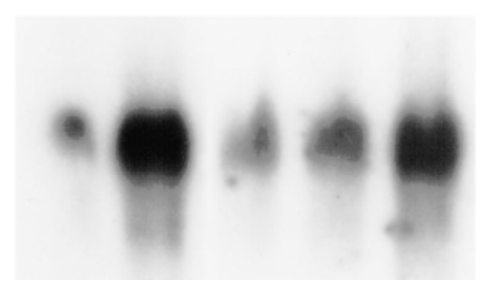

Figure 2. Northern blot analysis of thymic RNA from $T p^{+/+}$and $T p^{-1-}$ mice. Total RNA was extracted from thymus and $15 \mu \mathrm{g}$ of total RNA/sample was separated on glyoxal/dimethyl sulfoxide agarose gels, transferred onto nylon membranes, and then hybridized to a ${ }^{32} \mathrm{P}$-labeled antisense riboprobe. $(A)$ Hybridization with the antisense TP receptor riboprobe. $(B)$ Hybridization with a $\beta$-actin antisense riboprobe to assess equivalency of RNA loading.

distribution of T cells (Thy1.2 $2^{+}$staining) or specific T cell populations $\left(\mathrm{CD}^{+}\right.$or $\left.\mathrm{CD}^{+}\right)$between $T p^{-1-}$ and wild-type mice. $\mathrm{FACS}^{\circledast}$ analysis revealed no differences between $T p^{-/-}$and $\mathrm{Tp}^{+/+}$mice in the number of single positive, $\mathrm{CD} 4^{+}$or $\mathrm{CD} 8^{+}, \mathrm{T}$ cells or double positive, $\mathrm{CD} 4^{+} \mathrm{CD} 8^{+}$, $\mathrm{T}$ cells within the thymus. In addition, there were no differences in the number of total $\mathrm{T}$ cells, $\mathrm{CD}^{+}{ }^{+} \mathrm{T}$ cells, $\mathrm{CD}^{+} \mathrm{T}$ cells, $\mathrm{B}$ cells, or macrophages in spleen of wild-type and $T p^{-1-}$ mice.

$T P$ receptor autoradiography in kidney. In previous studies, we used receptor autoradiography to visualize the distribution and characteristics of thromboxane binding sites in mouse kidney (27). To define the effect of the TP receptor mutation on renal binding, we performed receptor autoradiography in $T p^{+/+}$and $T p^{-/-}$mice using the TP receptor agonist ${ }^{125}$ I-BOP.

Table I. Physiological Effects of the Tp Mutation

\begin{tabular}{lcccc}
\hline Tp genotype & $\begin{array}{c}{ }^{125} \text { I-BOP } \\
\text { binding } \\
\text { in thymocytes }\end{array}$ & $\begin{array}{c}\text { Systolic } \\
\text { blood } \\
\text { pressure }\end{array}$ & $\begin{array}{c}\text { Mean } \\
\text { arterial } \\
\text { pressure }\end{array}$ & $\begin{array}{c}\text { Bleeding } \\
\text { time }\end{array}$ \\
\hline & $\%$ specific counts & $m m H g$ & $m m g$ & $s$ \\
$T p^{+/+}$ & $0.60 \pm 0.29$ & $121 \pm 5$ & $93 \pm 4$ & $96 \pm 8$ \\
$T p^{-/-}$ & $0.01 \pm 0.01 *$ & $114 \pm 3$ & $100 \pm 4$ & $>600^{\ddagger}$ \\
& & & & \\
\hline
\end{tabular}

* $P=0.0008$ vs. $T p^{+/+},{ }^{\ddagger} P<0.0001$ vs. $T p^{+/+}$.
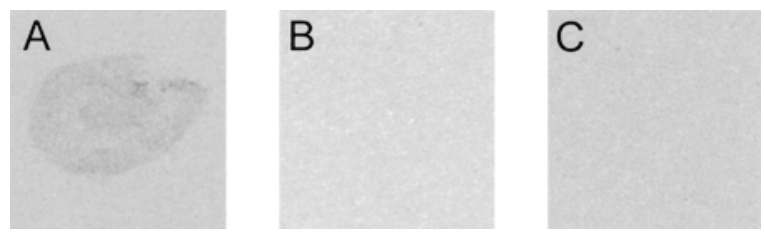

Figure 3. TP receptor autoradiography using the TP receptor agonist ${ }^{125}$ I-BOP. $(A)$ Total ${ }^{125} \mathrm{I}$-BOP binding in $T p^{+/+}$mouse kidney sections. (B) Nonspecific ${ }^{125}$ I-BOP binding in $T p^{+/+}$mouse kidney sections in the presence of excess unlabeled IBOP. $(C)$ Total ${ }^{125}$ I-BOP binding in $T p^{-1-}$ mouse kidney sections.

Specific ${ }^{125}$ I-BOP binding sites are present throughout the renal cortex and medulla in $T p^{+/+}$mice (Fig. $3 A$ ). In contrast, no ${ }^{125}$ I-BOP binding could be detected in kidney sections from $T p^{-l-}$ mice (Fig. $3 \mathrm{C}$ ).

Bleeding time assessment in Tp-deficient mice. $\mathrm{TXA}_{2}$ is a potent stimulator of platelet aggregation in vitro (41) and naturally occurring mutations of the $T p$ gene cause abnormal bleeding in humans (42). Therefore, we determined bleeding times in $\mathrm{Tp}^{-1-}$ mice. As shown in Table I, bleeding times averaged $96 \pm 5 \mathrm{~s}$ in conscious, wild-type mice $(n=11)$. However, in the $T p^{-1-}$ mice, bleeding times were markedly prolonged $(P<0.0001$ vs. wild-type); all of the $T p$-deficient mice continued to bleed for the entire 10-min observation period $(n=6)$. Because pharmacological antagonism of the TP receptor has only minimal effects on bleeding time in humans, we also measured bleeding time in wild-type mice $(n=6)$ that had been pretreated with an intravenous infusion of $10 \mathrm{mg} / \mathrm{kg}$ of the TP receptor antagonist SQ-29,548. Bleeding times were similarly prolonged ( $>10 \mathrm{~min}$ in all animals) in these wild-type mice in which TP receptors were blocked pharmacologically (43).

Platelet aggregation responses in $\mathrm{Tp}^{-/-}$mice. To examine platelet function in $\mathrm{Tp}^{-/-}$mice, we performed a series of platelet aggregation studies. As depicted in Fig. 4, the thromboxane agonist U-46619 induced vigorous aggregation of platelets in wild-type mice ( $81 \pm 5 \%$ aggregation) but caused no detectable aggregation of platelets from $T p^{-1-}$ mice $(3 \pm 1 \%$ aggregation, $P<0.0001$ vs. wild-type). We also tested whether the absence of TP receptors affected responses to the other platelet ago-

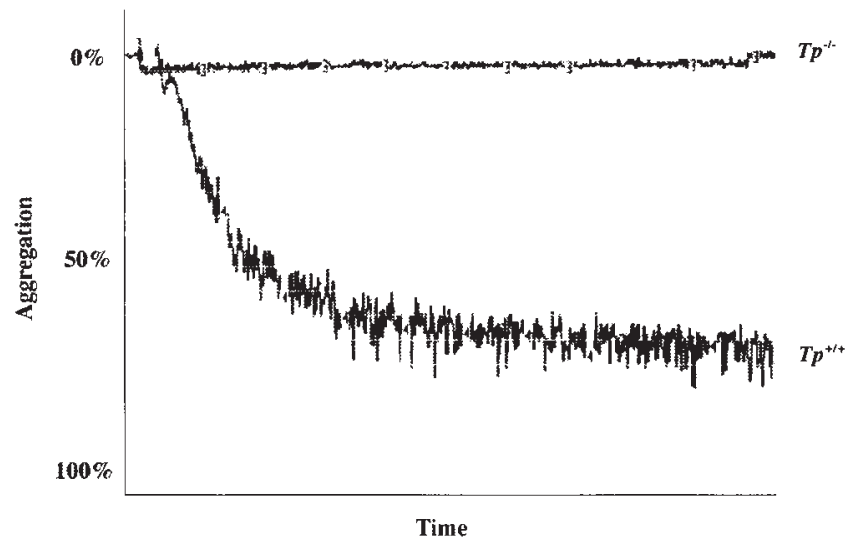

Figure 4. Platelet aggregation induced by the TP receptor agonist U-46619 in $T p^{+/+}$and $T p^{-/-}$mice. U-46619 caused rapid aggregation of platelets from $T p^{+/+}$mice, but had no discernible effect on platelets from $T p^{-1-}$ mice. 
nists. After collagen treatment, the delay period $(79 \pm 7 \mathrm{~s})$ before platelet aggregation occurred was significantly longer in $T p^{-l-}$ PRP compared with controls $(50 \pm 5 \mathrm{~s}, P=0.0047$ vs. $T p^{-1-}$ PRP). However, the maximum aggregation was similar between the two groups. There was no difference in platelet aggregation responses induced by addition of ADP to PRP from $T p^{+/+}$or $T p^{-/-}$mice.

Systolic blood pressure in $\mathrm{Tp}^{-/-}$mice. Previous studies have suggested a role for the TP receptors in the regulation of blood pressure and hemodynamic responses in various models of hypertension, vascular disease, and shock (44). To determine whether the absence of TP receptors affected blood pressure homeostasis, we measured systolic blood pressure in conscious mice using an automated tail cuff system as described previously (37). Systolic blood pressure tended to be lower in the $\mathrm{Tp}^{-1-}$ mice $(114 \pm 3 \mathrm{mmHg})$ than controls $(121 \pm 5 \mathrm{mmHg})$, but this difference was not statistically significant. Similarly, MAP was not different in anesthetized $T p^{+/+}(93 \pm 4 \mathrm{mmHg})$ and $T p^{-1-}(100 \pm 4)$ mice.

Cardiovascular responses to infusions of a thromboxane receptor agonist or arachidonic acid. Intravenous administration of either TP receptor agonist or arachidonic acid causes a syndrome of cardiovascular collapse and sudden death associated with systemic platelet aggregation, pulmonary thrombosis, and coronary spasm (45). To determine the effects of the $T p$ mutation on these responses, we first infused successive boluses of $100 \mu \mathrm{g} / \mathrm{kg}$ and $1 \mathrm{mg} / \mathrm{kg}$ U-46619 intravenously into anesthetized $T p^{-/-}$and wild-type mice while simultaneously monitoring MAP. As can be seen in Fig. 5, the low dose of U-46619 $(0.1 \mathrm{mg} / \mathrm{kg})$ caused a transient rise in blood pressure in wildtype animals. The maximal increase of $21 \pm 2 \mathrm{mmHg}$ occurred $60 \mathrm{~s}$ after U-46619 infusion and MAP returned to baseline levels after $120 \mathrm{~s}$. The higher dose of thromboxane agonist also caused a transient, early increase in MAP in $T p^{+/+}$mice. However, 2-3 min after administration of $1 \mathrm{mg} / \mathrm{kg}$ U-46619, MAP began to drop precipitously in the wild-type animals. This was followed by rapid hemodynamic collapse. After receiving the highest dose of U-46619, none of the three $T p^{+/+}$animals sur- vived beyond 6 min. In contrast, as shown in Fig. 5, U-46619 had no detectable effect on MAP in the $T p^{-1-}$ mice. All four $T p^{-/-}$mice survived to the end of the experiment.

The $T p$ mutation also caused a substantial alteration in the hemodynamic responses to arachidonic acid. As depicted in Fig. 6, MAP began to fall in the wild-type animals within $120 \mathrm{~s}$ after infusion of arachidonic acid. Cardiovascular collapse and shock rapidly ensued. None of the five $T p^{+/+}$animals survived beyond $300 \mathrm{~s}$ after infusion of the arachidonic acid. As illustrated in Fig. 6, arachidonic acid also caused a significant lowering of MAP in the $T p^{-1-}$ mice. However, while MAP fell by $\sim 25 \mathrm{mmHg}$ in $T p^{-1-}$ mice, the animals remained stable at this reduced level of MAP through the remainder of the experiment. All five $T p^{-1-}$ animals survived to the end of the experiment.

\section{Discussion}

To assess the role of the thromboxane receptor in development and in the regulation of physiological functions, we used gene targeting to disrupt the $T p$ locus. $T p$ null mutant mice are born in the expected Mendelian ratios and appear normal and healthy, suggesting that the TP receptor does not have a unique role in development or in promoting perinatal survival. $\mathrm{TP}$ receptors are expressed at high levels in the placenta and uterus and it has been suggested that these receptors may play a functional role in pregnancy, gestation, or delivery. However, we found that $T p^{-1-}$ females have normal frequency of productive matings, viable, normal size litters, and provide normal care for their offspring. Thus, if the TP receptor is involved in perinatal processes, it is not indispensable.

One of the tissues with the highest level of TP receptor expression is the thymus (21). Within the thymus, the TP receptor is expressed most highly by immature thymocytes. Exposure of these cells to $\mathrm{TXA}_{2}$ agonists causes apoptosis, suggesting that $\mathrm{TXA}_{2}$ may play a role in thymic selection (9). Based on these data, we performed careful analysis of thymic architecture and cellular composition. Although TP receptor

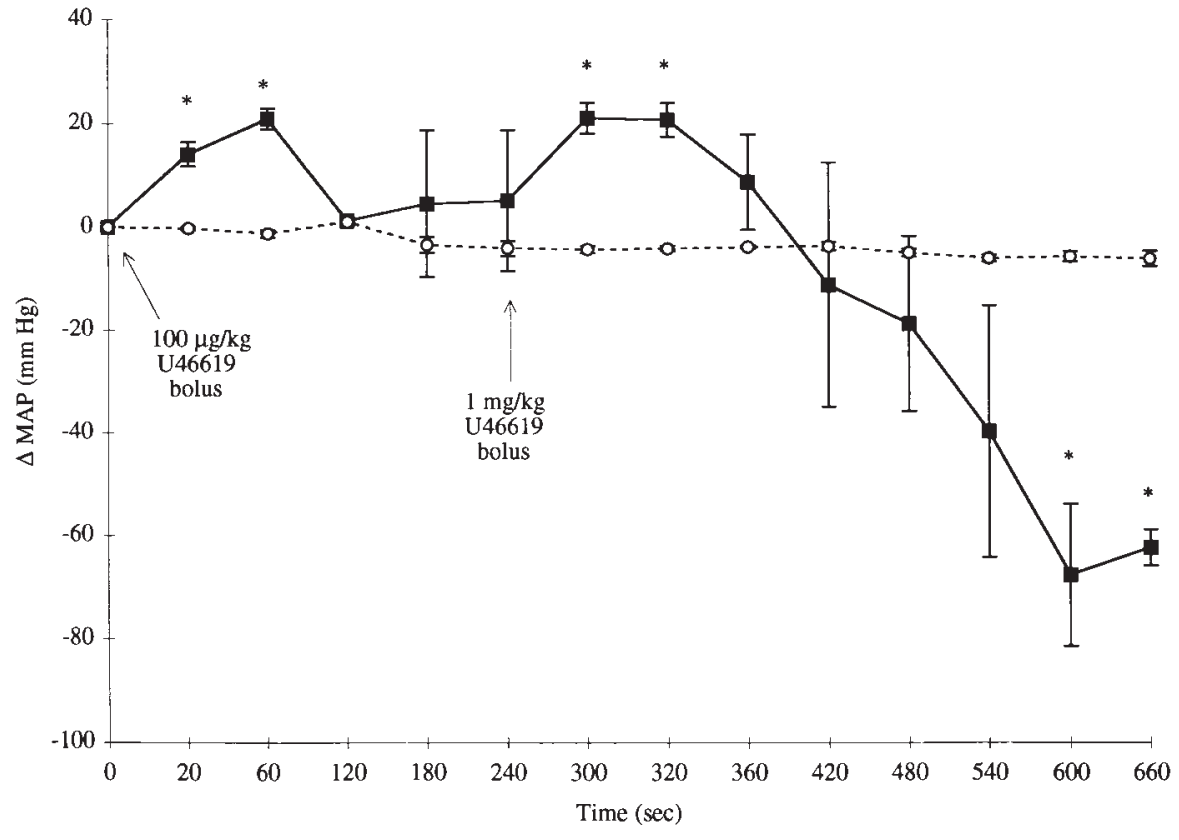

Figure 5. Hemodynamic effects of the intravenous TP receptor agonist U-46619 infusion. Data are expressed as the change in MAP compared with baseline, pretreatment values. Black squares represent wildtype mice $(n=4)$, whereas white circles represent the $T p^{-1-}$ mice. ${ }^{*} P \leq 0.003$ vs. wild-type. 


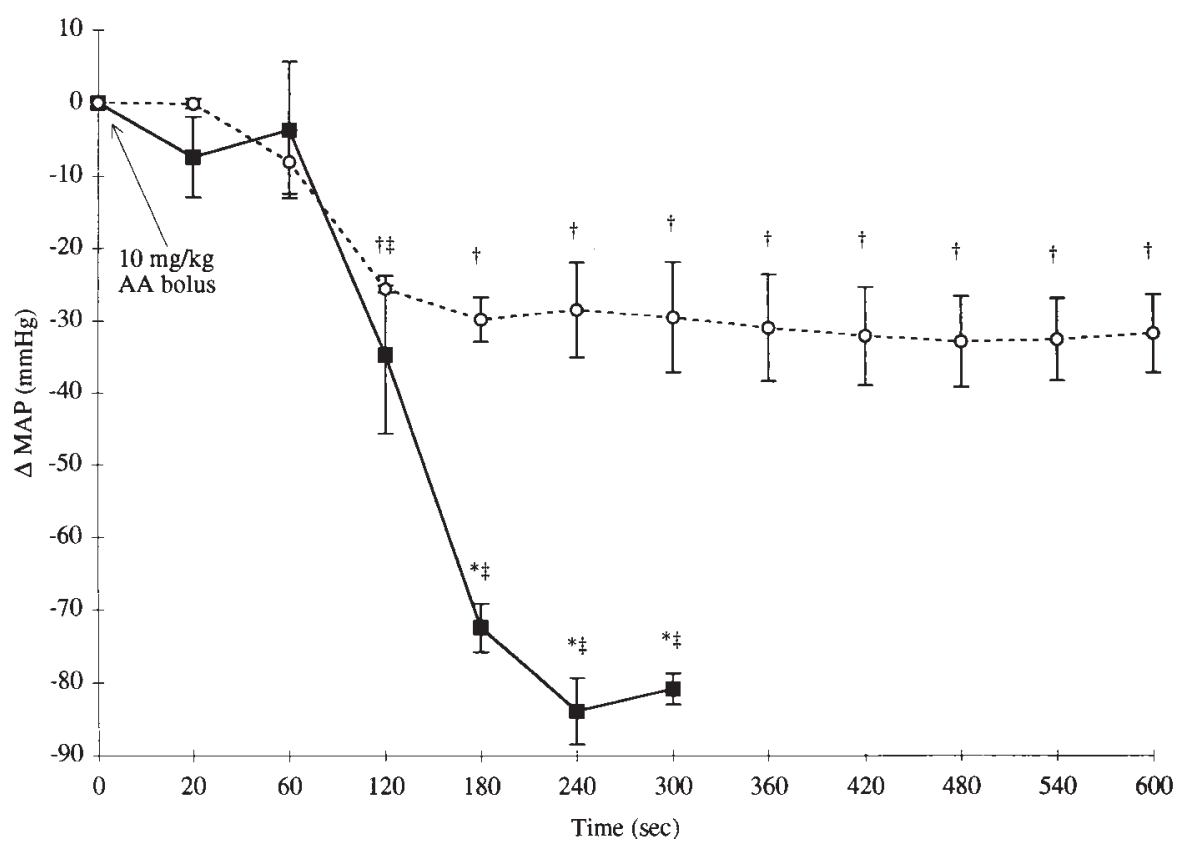

Figure 6. Hemodynamic effects of intravenous arachidonic acid infusion. Data are expressed as the change in MAP compared with baseline, pretreatment values. Black squares represent wild-type mice $(n=4)$, whereas white circles represent $T p^{-1-}$ mice $(n=4) . * P \leq 0.01$ vs. $T p^{-1-}$ mouse $\Delta$

MAP, ${ }^{\dagger} P \leq 0.018$ vs. baseline, ${ }^{\ddagger} P \leq 0.0325$ vs. baseline. agonist binding is not detectable in thymocytes from $T p^{-1-}$ mice, the structure of their thymuses is normal by histological examination. Immunohistochemical staining shows no difference in the distribution of double $\left(\mathrm{CD} 4^{+} \mathrm{CD} 8^{+}\right)$or single $\left(\mathrm{CD}^{+}\right.$or $\left.\mathrm{CD}^{+}\right)$staining thymocytes within the thymic cortex and medulla, respectively. When thymocytes from wild-type and $T p^{-1-}$ mice were analyzed by flow cytometry, we found no significant differences in their composition or expression of major cell surface markers. These data suggest that absence of the TP receptors from thymus does not substantially alter its structure or cellular composition.

Previously, we used receptor autoradiography to map $\mathrm{TXA}_{2}$ binding sites within the adult mouse kidney and found significant numbers of binding sites in both the renal cortex and medulla (27). Analysis of ligand displacement kinetics revealed distinct high-affinity binding sites in the cortex and a predominance of low-affinity sites in the renal medulla. Although the human TP gene encodes two isoforms of the TP receptor (46), we could not detect alternative splicing of the TP receptor mRNA using RT-PCR. To assess whether there might be multiple TP receptor isoforms encoded by additional genes, we performed receptor autoradiography on $\mathrm{Tp}^{+/+}$and $T p^{-1-}$ mice using the TP receptor agonist ${ }^{125} \mathrm{I}-\mathrm{BOP}$. Neither cortical nor medullary binding was detected in $T p^{-1-}$ mouse kidney. This suggests that all of these binding sites arise from the single known $T p$ gene locus. Thus, we conclude that if TP receptors in the kidney exist in varying affinity states, they are still products of a single gene.

TP receptors are also expressed at high levels in platelets. Stimulation of this receptor causes $\mathrm{TXA}_{2}$ synthesis, and platelet activation and aggregation (47). The marked prolongation of bleeding time in $T p^{-1-}$ mice confirms the importance of this pathway in promoting hemostasis. To determine whether the bleeding defect in $T p^{-1-}$ mice is associated with alterations in platelet function, we examined platelet aggregation responses in TP receptor-deficient mice. In wild-type mice, the TP receptor agonist U-46619 causes rapid, irreversible platelet aggregation. In contrast, platelets from $T p$-deficient mice are unre- sponsive to TP receptor agonist treatment. Thus, disruption of the known $T p$ gene locus completely eliminates $\mathrm{TXA}_{2}$-mediated platelet aggregation.

$\mathrm{TXA}_{2}$ may have diverse effects on platelet activation and aggregation including direct effects of $\mathrm{TXA}_{2}$ binding to the platelet TP receptor described above. Alternatively, $\mathrm{TXA}_{2}$ may promote platelet aggregation by amplifying activation signals of less potent agonists (48). To examine the contribution of TP receptors to other pathways for platelet activation, we assessed aggregation of $T p^{-1-}$ PRP in response to ADP and collagen. Unlike $\mathrm{TXA}_{2}$, ADP causes a reversible aggregation profile in mice but does not trigger the platelet release reaction (49). When PRP from wild-type or $T p^{-1-}$ mice was exposed to ADP, there was no significant difference in the platelet aggregation responses. These results demonstrate that the TP receptor does not play a significant role in ADPinduced platelet aggregation in mice. This differs from human platelets where ADP causes a reversible aggregation followed by a secondary wave of irreversible aggregation that is dependent on $\mathrm{TXA}_{2}$ (50).

Platelets bind to collagen via the cell surface GpIa-IIa receptor ( $\alpha 2 \beta 1$ integrin) $(51,52)$, and this binding triggers the activation of a series of several secondary messenger systems and results in platelet aggregation (47). A role for the TP receptor in this process is confirmed by our observation that the interval between collagen exposure and the onset of platelet aggregation was prolonged in TP receptor-deficient platelets compared with controls. Previous studies had suggested that GpIa-IIa receptor stimulation activates phospholipase $\mathrm{A}_{2}$ which generates $\mathrm{TXA}_{2}$ augmenting the activation signals from other second messenger systems $(47,51,53)$. Since the maximal aggregation response was similar between wild-type and $T p^{-1-}$ mice, other activation signals can eventually induce platelet aggregation in the absence of TP receptors. Furthermore, the preserved maximal responses of TP receptor-deficient PRP to ADP and collagen treatment may explain the lack of significant bleeding in $T p^{-1-}$ mice during procedures such as tail biopsy or catheter placement. 
Intravenous administration of the $\mathrm{TXA}_{2}$ mimetic U-46619 induces a shock syndrome characterized by cardiovascular collapse and sudden death. This syndrome is associated with systemic platelet aggregation, pulmonary thrombosis, and coronary spasm $(45,54,55)$ and suggests a role for $\mathrm{TXA}_{2}$ septic shock. To determine the role of the $T p$ gene locus in mediating these effects, we monitored the hemodynamic effect of U-46619 infusion in $T p^{-/-}$and wild-type mice (Fig. 5). In $T p^{+/+}$mice, the lowest dose of this TP receptor agonist caused transient vasoconstriction whereas the higher dose induced rapid cardiovascular collapse. In contrast, infusion of U-46619 had no detectable effect on systemic hemodynamics in $T p^{-1-}$ mice, suggesting that these actions are mediated exclusively by TP receptors.

Infusion of arachidonic acid also causes shock and sudden death $(43,56-58)$. Similar to the effects of U-46619, $\mathrm{Tp}^{-1-}$ mice are resistant to hemodynamic collapse induced by arachidonic acid, demonstrating that the effects of arachidonic acid infusion to induce sudden death are mediated primarily by TP receptors. Unlike U-46619, which had no detectable effect on $T p^{-1-}$ mice, infusion of arachidonic acid significantly lowered MAP in $T p^{-1-}$ mice. Although the mechanism of this effect is not clear from our studies, we suggest that this effect may be caused by enhanced production of vasodilatory eicosanoids such as prostaglandin $\mathrm{E}_{2}$ and prostaglandin $\mathrm{I}_{2}$ (prostacyclin), which are produced from arachidonic acid substrate.

In summary, these studies have identified a critical role for the $T p$ gene locus in hemostasis and in mediating vascular responses to arachidonic acid and $\mathrm{TXA}_{2}$ agonists. The absence of functional TP receptors has no effect on normal development or survival. Our studies provide strong evidence that most of the known functions of $\mathrm{TXA}_{2}$ can be accounted for by the single known $T p$ gene locus. These $T p^{-1-}$ mice will be valuable tools for assessing the role of TP receptors in disease states.

\section{Acknowledgments}

The authors would like to thank Norma B. Turner for administrative assistance, Dr. Dennis Lubahn for providing the mouse ES cell line E14tg2a genomic DNA library, Dr. Perry Halushka for providing ${ }^{125} \mathrm{I}-$ BOP for receptor autoradiography, and Chris Best and Nicole Hasbrouck for technical assistance.

Dr. Thomas performed these studies as a fellow of the National Kidney Foundation. These studies were supported by the Research Service of the Department of Veterans Affairs and the National Institutes of Health (HL58554, HL49277, AI001389, and DK38108).

\section{References}

1. Needleman, P., J. Turk, B.A. Jakschik, A.R. Morrison, and J.B. Lefkowith. 1986. Arachidonic acid metabolism. Ann. Rev. Biochem. 55:69-102.

2. Remuzzi, G., G.A. FitzGerald, and C. Patrono. 1992. Thromboxane synthesis and action within the kidney. Kidney Int. 41:1483-1493.

3. FitzGerald, G.A., C. Healy, and J. Daugherty. 1987. Thromboxane $\mathrm{A}_{2}$ biosynthesis in human disease. Fed. Proc. 46:154-158.

4. Baylis, C. 1987. Effects of administered thromboxanes on the intact, normal rat kidney. Renal Physiol. 10:110-121.

5. Mene, P., and M. Dunn. 1986. Contractile effects of TxA 2 and endoperoxide analogues on cultured rat glomerular mesangial cells. Am. J. Physiol. 251: F1029-F1035.

6. Wilcox, C.S., W.J. Welch, and H. Snellen. 1991. Thromboxane mediates renal hemodynamic response to infused angiotensin II. Kidney Int. 40:10901097.

7. Welch, W.J., and C.S. Wilcox. 1992. Potentiation of tubuloglomerular feedback in the rat by thromboxane mimetic. Role of macula densa. J. Clin. In- vest. 89:1857-1865.

8. Burch, R.M., and P.V. Halushka. 1982. Vasopressin stimulates prostaglandin and thromboxane synthesis in toad bladder epithelial cells. Am. J. Physiol. 243:F593-F597.

9. Ushikubi, F., Y. Aiba, K. Nakamura, T. Namba, M. Hirata, O. Mazda, Y. Katsura, and S. Narumiya. 1993. Thromboxane $\mathrm{A}_{2}$ receptor is highly expressed in mouse immature thymocytes and mediates DNA fragmentation and apoptosis. J. Exp. Med. 178:1825-1830.

10. Ruiz, P., L. Rey, R. Spurney, T. Coffman, and A. Viciana. 1992. Thromboxane augmentation of alloreactive $\mathrm{T}$ cell function. Transplantation. 54:498505 .

11. Ceuppens, J.L., S. Vertessen, H. Deckmyn, and J. Vermylen. 1985. Effects of thromboxane $\mathrm{A}_{2}$ on lymphocyte proliferation. Cell. Immunol. 90:458463.

12. Patrono, C., P. Patrignani, and G. Davi. 1993. Thromboxane biosynthesis and metabolism in cardiovascular and renal disease. J. Lipid Mediat. 6:411415 .

13. Devillier, P., and G. Bessard. 1997. Thromboxane $A_{2}$ and related prostaglandins in airways. Fund. Clin. Pharmacol. 11:2-18.

14. Brown, M.A. 1995. The physiology of pre-eclampsia. Clin. Exp. Pharmacol. Physiol. 22:781-791.

15. Smith, M.A. 1993. Preeclampsia. Prim. Care. 20:655-664.

16. Craven, P.A., M.F. Melhem, and F.R. DeRubertis. 1992. Thromboxane in the pathogenesis of glomerular injury in diabetes. Kidney Int. 42:937-946.

17. DeRubertis, F.R., and P.A. Craven. 1993. Eicosanoids in the pathogenesis of the functional and structural alterations of the kidney in diabetes. Am. J. Kidney Dis. 22:727-735.

18. Endoh, M., A. Kashem, F. Yamauchi, N. Yano, Y. Nomoto, H. Sakai, and K. Kurokawa. 1997. Expression of thromboxane synthase in kidney tissues from patients with IgA nephropathy. Clin. Nephrol. 47:168-175.

19. Coleman, R.A., W.L. Smith, and S. Narumiya. 1994. VIII. International union of pharmacology classification of prostanoid receptors: properties, distribution, and structure of the receptors and their subtypes. Pharmacol. Rev. 46: 205-229.

20. Hirata, M., Y. Hayashi, F. Ushikubi, Y. Yokota, R. Kageyama, S. Nakanishi, and S. Narumiya. 1991. Cloning and expression of cDNA for a human thromboxane $\mathrm{A}_{2}$ receptor. Nature. 349:617-620.

21. Namba, T., Y. Sugimoto, M. Hirata, Y. Hayashi, A. Honda, A. Watabe, M. Negishi, A. Ichikawa, and S. Narumiya. 1992. Mouse thromboxane $\mathrm{A}_{2}$ receptor: cDNA cloning, expression and Northern blot analysis. Biochem. Biophys. Res. Commun. 184:1197-1203.

22. Abe, T., K. Takeuchi, N. Takahashi, E. Tsutsumi, Y. Taniyama, and K. Abe. 1995. Rat kidney thromboxane receptor: molecular cloning, signal transduction, and intrarenal expression localization. J. Clin. Invest. 96:657-664.

23. Mais, D.E., D.L. Saussy, Jr., A. Chaikhouni, P.J. Kochel, D.R. Knapp, N. Hamanaka, and P.V. Halushka. 1985. Pharmacologic characterization of human and canine thromboxane $\mathrm{A}_{2}$ /prostaglandin $\mathrm{H}_{2}$ receptors in platelets and blood vessels: evidence for different receptors. J. Pharmacol. Exp. Ther. 233: 418-424.

24. Mais, D., D. DeHoll, J. Sightler, and P. Halushka. 1988. Different pharmacologic activities for 13-azapinane thromboxane $\mathrm{A}_{2}$ analogs in platelet and blood vessels. Eur. J. Pharmacol. 148:309-315.

25. Furci, L., D. Fitzgerald, and G. Fitzgerald. 1991. Heterogeneity of prostaglandin contraction and platelet aggregation. J. Pharmacol. Exp. Ther. 258: $74-81$.

26. Folger, W., P. Halushka, C. Wilcox, and N. Guzman. 1992. Characterization of rat glomerular thromboxane $\mathrm{A}_{2}$ receptors: comparison to rat platelets. Eur. J. Pharmacol. 227:71-78.

27. Mannon, R.B., T.M. Coffman, and P.J. Mannon. 1996. Distribution of binding sites for thromboxane $\mathrm{A}_{2}$ in the mouse kidney. Am. J. Physiol. 271: F1131-F1138.

28. Takahara, K., R. Murray, G. Fitzgerald, and D. Fitzgerald. 1990. The response to thromboxane $\mathrm{A}_{2}$ analogues in human platelets: discrimination of two binding sites linked to distinct effector systems. J. Biol. Chem. 265:6836-6844.

29. Spurney, R.F., J.J. Onorato, F.J. Albers, and T.M. Coffman. 1993. Thromboxane binding and signal transduction in rat glomerular mesangial cells. Am. J. Physiol. 264:F292-F299.

30. Simmons, T., J. Cook, J. Moore, and P. Halushka. 1993. Thromboxane $\mathrm{A}_{2}$ receptors in equine monocytes: identification of a new subclass of $\mathrm{TXA}_{2}$ receptors. J. Leukocyte Biol. 53:173-178.

31. Nusing, R.M., M. Hirata, A. Kakizuka, T. Eki, K. Ozawa, and S. Narumiya. 1993. Characterization and chromosomal mapping of the human thromboxane $\mathrm{A}_{2}$ receptor gene. J. Biol. Chem. 268:25253-25259.

32. Mohn, A., and B. Koller. 1995. Manipulation of embryonic stem cells. In DNA Cloning. Vol. 4. D. Glover and B. Hames, editors. Oxford University Press, New York. 143-184.

33. Sambrook, J., E.F. Fritsch, and T. Maniatis. 1989. Molecular Cloning: A Laboratory Manual. Cold Spring Harbor Laboratory, Cold Spring Harbor, NY. 34. Morinelli, T., J. Oatis, A. Okwa, D. Mais, P. Mayeux, A. Masuda, D. Knapp, and P. Halushka. 1989. Characterization of an ${ }^{125}$ I-labeled thromboxane $\mathrm{A}_{2}$ /prostaglandin $\mathrm{H}_{2}$ receptor agonist. J. Pharmacol. Exp. Ther. 251:557-562. 35. Mannon, R., B. Kotzin, E. Roper, C. Nataraj, R. Kurlander, and T. 
Coffman. 1996. The intragraft $\mathrm{CD}^{+} \mathrm{T}$ cell response in renal allograft rejection in the mouse. Transplantation. 62:96-104.

36. Dejana, E., A. Callioni, A. Quintana, and G. de Gaetano. 1979. Bleeding time in laboratory animals. II. A comparison of different assay conditions in rats. Thromb. Res. 15:191-197.

37. Krege, J., J. Hodgin, J. Hagamin, and O. Smithies. 1995. A computerized system for measuring blood pressure in mice. Hypertension. 25:1111-1115.

38. Kim, H.S., J.H. Krege, K.D. Kluckman, J.R. Hagaman, J.B. Hodgin, C.F. Best, J.C. Jennette, T.M. Coffman, N. Maeda, and O. Smithies. 1995. Genetic control of blood pressure and the angiotensinogen locus. Proc. Natl. Acad. Sci. USA. 92:2735-2739.

39. Ito, M., M.I. Oliverio, P.J. Mannon, C.F. Best, N. Maeda, O. Smithies, and T.M. Coffman. 1995. Regulation of blood pressure by the type $1 \mathrm{~A}$ angiotensin II receptor gene. Proc. Natl. Acad. Sci. USA. 92:3521-3525.

40. Oliverio, M., C. Best, H. Kim, W. Arendshorst, O. Smithies, and T. Coffman. 1997. Angiotensin II responses in $\mathrm{AT}_{1 \mathrm{~A}}$ receptor-deficient mice: a role for $\mathrm{AT}_{1 \mathrm{~B}}$ receptors in blood pressure regulation. Am. J. Physiol. 272:F515F520.

41. Oates, J., G. Fitzgerald, R. Branch, E. Jackson, H. Knapp, and L. Roberts. 1988. Clinical implications of prostaglandin and thromboxane $\mathrm{A}_{2}$ formation. N. Engl. J. Med. 319:689-698.

42. Hirata, T., A. Kakizuka, F. Ushikubi, I. Fuse, M. Okuma, and S. Narumiya. 1994. Arg60 to Leu mutation of the human thromboxane $A_{2}$ receptor in a dominantly inherited bleeding disorder. J. Clin. Invest. 94:1662-1667.

43. Darius, H., and A.M. Lefer. 1985. Blockade of thromboxane and the prevention of eicosanoid-induced sudden death in mice. Proc. Soc. Exp. Biol. Med. 180:364-368.

44. Wilcox, C.S., J. Cardozo, and W.J. Welch. 1996. $\mathrm{AT}_{1}$ and $\mathrm{TxA}_{2} / \mathrm{PGH}_{2}$ receptors maintain hypertension throughout $2 \mathrm{~K}, 1 \mathrm{C}$ Goldblatt hypertension in the rat. Am. J. Physiol. 271:R891-R896.

45. Torres Duarte, A.P., P. Ramwell, and A. Myers. 1986. Sex differences in mouse platelet aggregation. Thromb. Res. 43:33-39.

46. Raychowdhury, M.K., M. Yukawa, L.J. Collins, S.H. McGrail, K.C. Kent, and J.A. Ware. 1994. Alternative splicing produces a divergent cytoplasmic tail in the human endothelial thromboxane $\mathrm{A}_{2}$ receptor [published erratum appears in J. Biol. Chem. 1995. 270:7011]. J. Biol. Chem. 269:19256-19261.

47. Arita, H., T. Nakano, and K. Hanasaki. 1989. Thromboxane $\mathrm{A}_{2}$ : its generation and role in platelet activation. Prog. Lipid Res. 28:273-301.

48. Ushikubi, F., M. Hirata, and S. Narumiya. 1997. Platelet prostaglandin receptors. In Platelets and Their Receptors. Vol. 126. F. von Bruchhausen and U. Walter, editors. Springer-Verlag, Berlin, Germany. 135-154.

49. Rosenblum, W.I., G.H. Nelson, C.S. Cockrell, and E.F. Ellis. 1983. Some properties of mouse platelets. Thromb. Res. 30:347-355.

50. Nunn, B. 1981. Some characteristics of mouse platelet aggregation and a comparison of the activity of a range of compounds in mouse and human platelet-rich plasma in vitro. Thromb. Haemost. 45:1-5.

51. Clemetson, K.J., and J. Polgar. 1997. Platelet adhesion and aggregation receptors. In Platelets and Their Factors. Vol. 126. F. von Bruchhausen and U. Walter, editors. Springer-Verlag, Berlin, Germany. 155-179.

52. van Zanten, G.H., P.G. de Groot, and J.J. Sixma. 1997. Platelet adhesion. In Platelets and Their Factors. Vol. 126. F. von Bruchhausen and U. Walter, editors. Springer-Verlag, Berlin, Germany. 61-81.

53. Halushka, P.V., S. Pawate, and M.L. Martin. 1997. Thromboxane A and other eicosanoids. In Platelets and Their Factors. Vol. 126. F. von Bruchhausen and U. Walter, editors. Springer-Verlag, Berlin, Germany. 459-482.

54. Yamamoto, T., K. Hosoki, and T. Karasawa. 1993. Possible involvemen of endothelin in thromboxane $\mathrm{A}_{2}$ receptor agonist (U-46619)-induced angina in the rat. Eur. J. Pharmacol. 250:189-191.

55. Yamamoto, T., C. Kikuta, and K. Hosoki. 1994. U-46619-induced ischaemic electrocardiographic changes in rats: preventive effects of prostacyclin and nitroglycerin. J. Pharm. Pharmacol. 46:558-562.

56. Seuter, F., E. Perzborn, and V.B. Fiedler. 1991. Effect of BAY U 3405, a new thromboxane antagonist, on arachidonic acid induced thromboembolism. Adv. Prostaglandin Thromboxane Leukotriene Res. 21A:355-358.

57. Myers, A.K., and P.W. Ramwell. 1985. Thromboxane in sudden death Adv. Prostaglandin Thromboxane Leukotriene Res. 13:81-88.

58. Pfister, S.L., D.A. Kotulock, and W.B. Campbell. 1997. Vascular smooth muscle thromboxane $\mathrm{A}_{2}$ receptors mediate arachidonic acid-induced sudden death in rabbits. Hypertension. 29:303-309. 